\title{
THE COVID-19 OUTBREAK`S EFFECTS AND NEW INCLINATIONS IN TERMS OF LOGISTICS AND SUPPLY CHAIN ACTIVITIES: A CONCEPTUAL FRAMEWORK
}

\author{
DOI: 10.17261/Pressacademia.2021.1408 \\ JMML- V.8-ISS.2-2021(1)-p.76-88
}

\section{Ozden Ozkanlisoy}

Istanbul Aydin University, Department of Aviation Management, Florya, Istanbul, Turkey. ozdenozkanlisoy@aydin.edu.tr, ORCID: 0000-0001-7879-0733

\begin{tabular}{l}
\hline Date Received: January 5, $2020 \quad$ Date Accepted: May 29, 2021 \\
\hline To cite this document \\
Ozkanlisoy, O. (2021). The COVID-19 outbreak`s effects and new inclinations in terms of logistics and supply chain activities: A Conceptual \\
Framework. Journal of Management, Marketing and Logistics (JMML), 8(2), 76-88. \\
Permanent link to this document: $\underline{\text { http://doi.org/10.17261/Pressacademia.2021.1408 }}$ \\
Copyright: Published by PressAcademia and limited licensed re-use rights only. \\
\hline
\end{tabular}

\section{ABSTRACT}

Purpose - The global pandemic called COVID-19 has also affected many economic sectors and activities, including manufacturing, supply chain and logistics. Undoubtedly, logistics and supply chain activities are the most crucial of them. There are not enough studies yet on the effect of COVID-19 on the logistics and supply chain. In this study, it is aimed to designate the effects of the pandemic on the logistics and supply chain activities, take measures against future crises and assist companies in risk management activities.

Methodology - The study is based on a literature review. The secondary data, published reports and academic studies on the field of supply chain and logistics during the COVID-19 pandemic period were examined and the findings were reported.

Findings- The COVID-19 pandemic has some negative effects on logistics and supply chain activities such as bullwhip effect, the decrease in the carrying capacity, the contraction of the international trade volume, which is an indispensable part of logistics, and the increase in logistics costs. Furthermore, pandemic has shown that many of the pre-pandemic approaches to supply chains were wrong. New approaches and strategies, which can be called new inclinations in the supply chain during the pandemic period, the understanding of localization in purchasing and the transition to new production areas, acceleration in digital transformation, increasing supply chain flexibility are the most significant ones.

Conclusion- When supply chains are faced with the risk of a natural disaster such as a pandemic, they must proactively conduct risk management efforts to mitigate this risk with minimal damage. Supply chain resistance should be increased. Moreover, companies must increase their investments in digital transformation and transform their supply chains into interconnected and autonomous ecosystems. These supply chains will be the winning supply chains of tomorrow.

Keywords: The effect of COVID-19, new inclinations in logistics and supply chains, risk management JEL Codes: M10, M20, G32

\section{INTRODUCTION}

"Logistics" is a concept that emerged with military organizations and was first introduced in XIV. Used in Louis France. Even then, the effectiveness of the organization did not depend solely on weapons and soldiers' strength and fighting enthusiasm. The effectiveness of the organization at that time also depended on transport facilities and efficient supply of ammunition and food items. At that time, the supply and transportation of materials, food, and ammunition was rationally considered, and this is logistics. The significance given to logistics played a crucial role in the French military success (Weele, 2014: 253).

Logistics is liable for the transportation and storage of materials moving along the supply chain (SC). By following the materials transported in a business, the activities included in logistics can be seen (Waters, 2003: 12). Logistics is not only an important concept for the efficiency of organizations for businesses. Since it contains the "movement" element that enables logistics organizations to move forward, operations related to the movement of goods and services cannot be carried out in businesses without logistics. (Shapiro, 1984: 119).

International SCs are more significant than ever for global trade. The key factor in a country's ability to affiliate with SCs is the local trade facilitation and the efficiency of its logistics activities (Freund and Rocha, 2011: 361). Even so the tariffs in export 
markets are zero, if companies in a country are faced with high costs and inefficient logistics, they will not be able to rival companies that capitalize on an efficient logistics environment (Hoekman, 2020). Therefore, logistics activities within the SC are a significant issue for the competition of both companies and countries.

In the 21st century, a new epidemic named COVID-19 was added to the list of global epidemics in 2019. The number of casualties caused by this pandemic is increasing day by day. The coronavirus pandemic, which is known to originate in Wuhan, China and has spread to all countries of the world in 2020, continues to affect many people worldwide by continuing its contagiousness (Kraemer et al., 2020: 493). The pandemic does not only affect human health. Natural disasters and crises are among the events that lead to disruptions in the SC. The pandemic also affected economic sectors and activities, including manufacturing, supply chain, and logistics (WHO, 2020).

The expected damage of the COVID-19 pandemic is difficult to predict. The global health crisis has turned into an economic crisis. Analyzes suggest that the economic effects of the coronavirus pandemic will be more advanced than the Great Depression that started in 1929 due to the USA (Gopinath, 2020). Changes in prevention policies and plans has occurred due to uncertain data on incidence rate, mortality, and other statistics. There are different applications in different parts of the World (Prichep, 2020; Singh et al., 2020: 3). However, while the damage at the end of the pandemic is difficult to predict, it is possible to examine the damage so far and set a roadmap for the rest of the pandemic. There are not enough studies yet on the impact of COVID-19 on the logistics and supply chain activities. In this study, it is aimed to designate the impacts of the pandemic on the logistics and supply activities, to take measures against future crises and to assist companies in risk management activities. For this purpose, the secondary data, published reports and academic studies on the field of supply chain and logistics during the COVID-19 pandemic period were examined and the findings were reported. The study ends with an evaluation of the findings and recommendations to supply chains and businesses regarding future risks.

\section{GLOBAL SUPPLY CHAIN RISKS}

Many major risks, both natural and anthropogenic, are increasing the interest of both academia and policy makers in global supply chain risks. Supply chain risks have many causes or drivers. These risks have become more diverse over time because of the increasing importance, length and complexity of global value chains (Saenz and Revilla, 2014). In a recent study of corporate executives (World Economic Forum, 2017), the risks, along with their degree of impact, are shown in Table 1 below (Anbumozhi et al., 2020: 5; World Economic Forum, 2017):

Table 1: Drivers of Global Supply Chain Risks

\begin{tabular}{|l|l|l|l|}
\hline Type of Risk & Risk & \% & \\
\hline \multirow{5}{*}{ Environmental } & Natural disasters & 59 & Uncontrollable \\
\cline { 2 - 4 } & Extreme weather & 30 & Uncontrollable \\
\cline { 2 - 4 } & Pandemic & 11 & Influenceable \\
\hline \multirow{5}{*}{ Geopolitical } & Conflicts and war & 46 & Influenceable \\
\cline { 2 - 4 } & Export/Import restrictions & 33 & Controllable \\
\cline { 2 - 4 } & Terrorism & 32 & Influenceable \\
\cline { 2 - 4 } & Corruption & 17 & Influenceable \\
\cline { 2 - 4 } & Organized crime & 15 & Influenceable \\
\cline { 2 - 4 } & Maritime piracy & 9 & Influenceable \\
\cline { 2 - 4 } & Nuclear/biological weapons & 6 & Influenceable \\
\hline \multirow{5}{*}{ Economic } & Sudden demand shocks & 44 & Influenceable \\
\cline { 2 - 4 } & Volatility in commodity prices & 30 & Influenceable \\
\cline { 2 - 4 } & Border delays & 26 & Influenceable \\
\cline { 2 - 4 } & Currency fluctuation & 26 & Controllable \\
\cline { 2 - 4 } & Global energy shortage & 19 & Influenceable \\
\cline { 2 - 4 } & Investment restrictions & 17 & Controllable \\
\cline { 2 - 4 } & Shortage of labor & 30 & Influenceable \\
\hline \multirow{3}{*}{ Technical } & Information and communication disruptions & Controllable \\
\cline { 2 - 4 } & Transport infrastructure & & \\
\hline
\end{tabular}

Reproduced from Source: Anbumozhi, V., Kimura, F., \& Thangavelu, S. M. (2020). Global supply chain resilience: vulnerability and shifting risk management strategies. In Supply Chain Resilience (pp. 3-14)., Singapore: Springer, p. 5. 
According to the results of the research on risk factors in global supply chains in Table 1 above, it is possible to say that the risks that have the most significant impact on supply chains are external risks such as natural disasters, sudden demand shocks and information interruptions. By distinguishing environmental, geopolitical, economic, and technological factors, the close relationships between global supply chain risks and other systemic risk categories can be better understood (Anbumozhi et al., 2020: 5).

The interest in supply chain vulnerability and its managerial counterpart, supply chain risk management, has attracted great interest from practitioners as well as academics over the past two decades (Rao and Goldsby, 2009). Supply chain risk management is defined as identifying potential risk sources and implementing appropriate strategies with a coordinated approach among supply chain risk members to reduce supply chain vulnerability. (Juttner, 2005: 120). The main purpose of supply chain risk management is to reduce supply chain vulnerability.

The COVID-19 pandemic has affected supply chains to a greater extent than the pandemic risk seen in the 2017 study. It is predicted that there will be more such epidemics in the globalizing world from now on. Moreover, these diseases are predicted to affect all societies indiscriminately. However, it cannot be predicted from which source, when or in what form the outbreaks will occur (Budak and Korkmaz, 2020: 75; Taşkın, 2020: 126). Some companies were better prepared during this period to reduce the impact of the supply chain disruption caused by COVID-19. These are companies that have developed and implemented supply chain risk management and business continuity strategies (Kilpatrick and Barter, 2020: 4).

\section{NEGATIVE IMPACTS ON LOGISTICS AND SUPPLY CHAIN MANAGEMENT}

The impact of COVID-19 is an interdisciplinary issue under discussion in social sciences. Supply chain and logistics are one of these disciplines (Ivanov, 2020: 2). With the impact of the pandemic, a two-way break occurred in the SCs. This break has affected both the overall economic situation and the supply chains and logistics activities as a whole. In addition, this pandemic has led to a review of many approaches and practices in supply chain and logistics. The negative impacts of coronavirus on the supply chain and logistics are explained in detail below:

\subsection{The Bullwhip Effect in SCs}

The forward growth of inventory and demand in a SC has been well known to SC managers for decades. This phenomenon is called the bullwhip effect, in which fluctuations in orders increase as they ascend the SC from retailer to wholesaler, producers and suppliers (Behzad et al., 2011: 556). The bullwhip effect is a major issue in supply chains that affects forecast quality and therefore increases demand fluctuations upstream of the supply chain (Lee et al.,1997: 546). Demand fluctuations bring about extra costs and affect delivery times (Hassan and Soh, 2005: 567; Disney et al., 2006: 151; Li and Gao, 2010: 1). The bullwhip effect causes inefficiency and is seen as one of the most significant performance indicators for supply chains. (Lichun and Jiayu, 2011: 2).

In pandemic situations such as COVID-19 (coronavirus), which have great effects by all countries of the world, the importance of the bullwhip effect in SCs has been better understood. During this pandemic, while the demand for many products and services increased, the demand for some decreased. The demand for many food and health products increased, market shelves were emptied, and prices increased. During the quarantine period, there was an increase in internet and home service services. Many businesses had to stop their production. This process is clearly demonstrating how the bullwhip effect occurs in the SC (Akbal, 2020: 182).

Strategies for the bullwhip effect in the supply chain are divided into two as demand management and capacity management. The demand management strategy is aimed at preventing the bullwhip effect, while the capacity management strategy is aimed at reducing the bullwhip effect. Therefore, while external factors are also effective in demand management, capacity management is only under the control of the organization. Since companies cannot affect the pandemic, which is an external factor, during the COVID-19 period, they should implement the capacity management strategy by taking their own companies under control. In this way, the bullwhip effect can be minimized. (Akkermans and Voss, 2013: 765). In addition, practices aimed at reducing the bullwhip effect in the supply chain include increasing the sharing and communication of supply information, reducing variability in demand, shortening the lead times, establishing strategic partnerships, reducing order sizes, allowing other organizations to manage the stocks of their suppliers (Hassan and Soh, 2005: 567). Forward and feedback mechanisms should be established to increase cooperation, integration and knowledge sharing in supply chains. Thus, the bullwhip effect can be reduced. (Viswanadham et al., 2005: 2994). 


\subsection{Transportion Capacity}

With the COVID-19 pandemic, restrictions have been imposed on drivers in freight transport on the road (Barua, 2020: 7). During the pandemic period, some of the road loads were transferred to the railway due to reasons such as the lack of driver supply to meet demand. In the first quarter of 2020, the number of freight trains serving between China and Europe increased by $15 \%$ to 1,941. In the same period, the number of containers transported increased by $18 \%$ to 174,000 (UNESCAP, 2020).

According to the estimates announced by the International Road Transport Union (IRU), the revenues of road freight transport companies will decrease by USD 679 billion in 2020. This amount will correspond to an $18 \%$ decrease in revenues compared to 2019 (IRU, 2020a: 4). While this loss of income is estimated to be 125 billion US dollars in Europe, 1 billion US dollars in Saudi Arabia, 63 billion US dollars in the USA and 131 billion US dollars in China are predicted (IRU, 2020b).

Transport activities have also been affected by the bullwhip effect caused by COVID-19. In maritime transport, import containers could not be emptied on time. This situation has increased the need for empty containers at export ports. This caused a significant increase in prices (LODER, 2020: 1). According to the data of the Drewry, the composite index increased $2 \%$ or $\$ 121$ on May 28 , 2021 , and remains $292.8 \%$ higher than a year ago. The average composite index of the World Container Index (WCI), assessed by Drewry for year-to-date, is $\$ 5,243$ per $40 \mathrm{ft}$ container, which is $\$ 3,348$ higher than the five-year average of $\$ 1,895$ per $40 \mathrm{ft}$ container. The change in the World Container Index (WCI) from May 2020 to May 2021 in the post-COVID-19 period is shown in Figure 1 below (Drewry, 2021):

Figure 1: The Change in Drewry World Container Index (WCI)- May 2020-May 2021

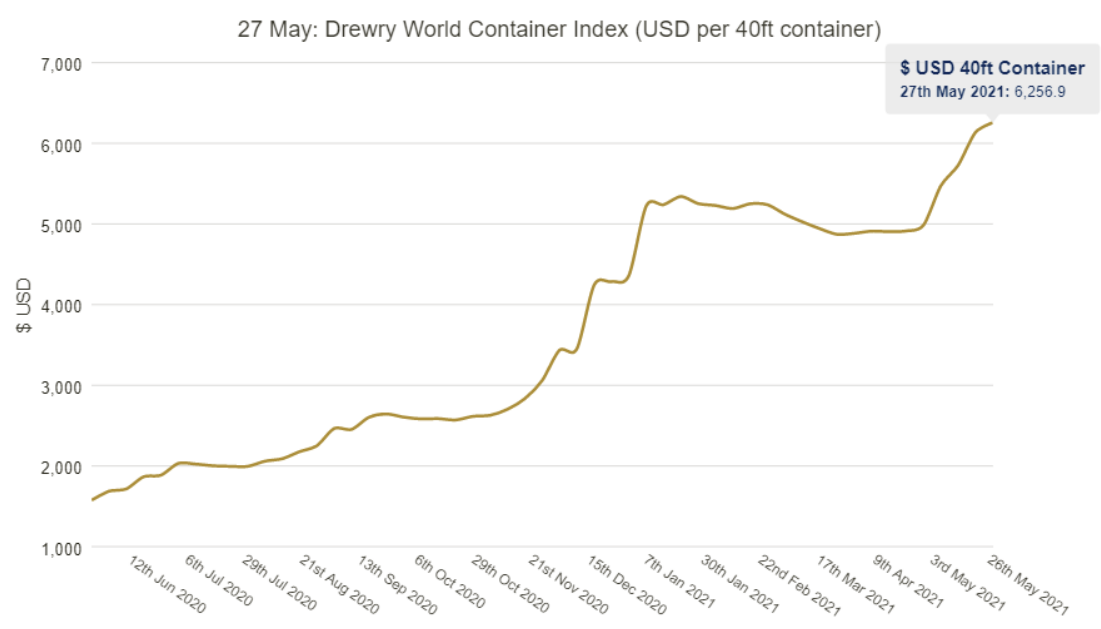

Source: Drewry, (2021). https://www.drewry.co.uk/supply-chain-advisors/supply-chain-expertise/world-container-index-assessed-by-drewry Accessed date: 28.05 .2021$.

From the point of view of air transport, this mode of transport has a large share in the rapid spread of the coronavirus (European Commission, 2020a: 1). Therefore, travel bans have been imposed around the world. During this period, air traffic fell rapidly and came to a standstill, with a decrease in airline passenger traffic and passenger revenues in all continents of the World (ICAO, 2020: 6- 10; $\mathrm{ACl}, 2020: 2$ ). The closure of airports to transportation has caused a significant impact on cargo transportation, although not as much as passenger transportation (Li, 2020: 1-6). In consequence of the developments with the COVID-19, airlines have suffered great financial losses and some of them have gone bankrupt. This situation forces airlines to make radical changes in their transportation strategies or to develop new strategies to minimize and compensate their financial losses (Albers and Rundshagen, 2020).

According to the data of the International Air Transport Association (IATA), although airlines have reduced their expenses by approximately 46\%, their losses in 2020 are USD 118 billion and the rate of decrease in demand compared to 2019 is $61 \%$. The loss in 2021 is estimated to be US $\$ 38.7$ billion (IATA, 2020a). When the 5-year development of the flight frequency across Europe is examined under three different scenarios, it is expected that the return to 2019 levels will be achieved in 2024 with the most 
optimistic scenario. If the coronavirus vaccine is not effective, that is, if the epidemic continues to be effective, it is predicted that the flight frequency will return to the levels of 2019 in 2029 (EUROCONTROL, 2020).

In terms of air cargo transportation, the unavailability of the cargo capacity of the passenger plane fleet puts pressure on the total air cargo capacity. Especially in April 2020, it was observed that the cargo plane capacity increased, while the passenger plane cargo capacity decreased due to the flight bans put into effect within the scope of the measures. The increase in cargo aircraft capacity was not sufficient to compensate for the loss of cargo capacity of passenger aircraft (IATA, 2020b: 2).

Due to the increasing freight prices and transit times in air and seaways, rail freight transportation has increased its competitive power due to the coronavirus pandemic. Furthermore, rail freight transport has emerged as a type of transport where international freight transport can be continued without interruption, since it is relatively exempt from the restrictions imposed on all other transport types (UIC, 2020: 30).

\subsection{Contraction in Trade Volume}

According to the general trade system, the exports of Turkey in January-December 2020 decreased by $6.3 \%$ according to the same period of the previous year, 169 billion 482 million dollars, imports increased by $4.3 \%$ was realized as 219 billion 397 million dollars. In the same period, the foreign trade deficit increased by $69.1 \%$ (TUIK, 2020).

When analyzed globally, the SC of countries connected to the global trade network such as China, South Korea, Italy, Japan, USA, and Germany has been interrupted due to the pandemic. The total trade intensity of these countries decreased from 0.833 to 0.429 in the period of 2018-2020 (1st Quarter) (Vidya and Prabheesh, 2020: 2410-2414). In the pre-COVID-19 era, global merchandise trade had grown for two consecutive years since 2016. In 2019, it was approximately $3 \%$ smaller than the previous year. When the impact of the coronavirus is examined, it is estimated that at the end of the first three quarters of 2020, there was a contraction of $11.9 \%$ according to the previous year (UNCTAD, 2020: 16). In addition, due to the contraction in the world economy and international trade, it was estimated that the world import volume will decrease by about $10 \%$ in 2020 (European Commission, 2020b: 3). Actual values for the world trade volume starting from first quarter of 2015 to the second quarter of 2020 and the estimates for the world trade volume from the third quarter of 2020 are shown in Figure 2 below (WTO, 2021):

Figure 2: World Merchandise Trade Volume- 2015 First Quarter (Q1)-2022 Fourth Quarter (Q4)

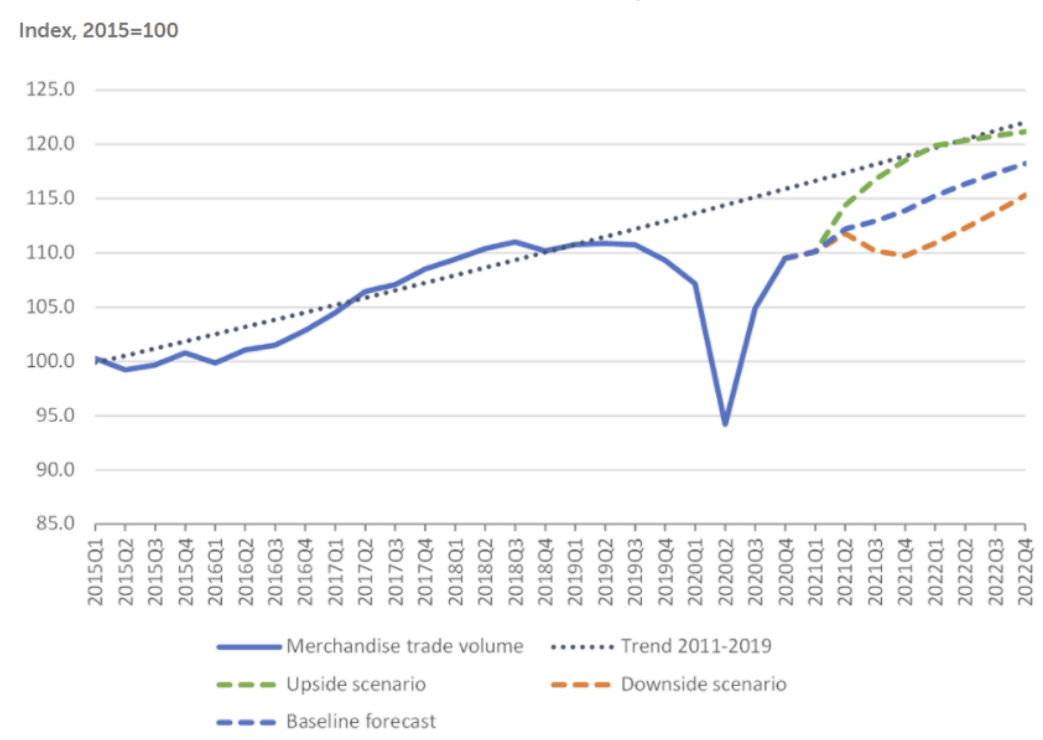

Source: WTO, (2021). World trade primed for strong but uneven recovery after COVID-19 pandemic shock. Retrieved from https://www.wto.org/english/news_e/pres21_e/pr876_e.htm. 29 May 2021

World trade has rebounded strongly after the shock of the COVID-19 pandemic, but there are two different scenarios for this recovery. The level of recovery will vary according to the rate of vaccination against COVID-19 disease. In this context, there are two different forecasts for 2021 and 2022. In the upside scenario, vaccine production and distribution are accelerated, and 
containment measures are relaxed earlier. According to this scenario, it is expected to add about 1 percent to world GDP growth and about 2.5 percent to world goods trade volume growth in 2021 . Trade will have returned to its pre-pandemic trend by the fourth quarter of 2021 (2021Q4). The downside scenario is that vaccine production does not meet the demand for vaccines or new variants of the virus appear where vaccines are less effective. According to the forecasts for this scenario, it could decrease by 1 percentage point from global GDP growth in 2021 and reduce trade growth by about 2 percentage points (WTO, 2021). The current situation so far and the forecasts for the future are shown in Figure 2 above.

\subsection{Increase in Logistics Costs}

Logistics costs have increased significantly during the COVID-19 period. One of the reasons for this is that the delay in the return of drivers to work as a result of the restriction of human mobility causes labor shortages and thus increases labor costs. Another reason is that logistics businesses bear the long-term costs of epidemic prevention and control (eg cost of disinfection of packages, cost of building non-contact delivery facilities) accomplishing enhanced operating costs. Other reason is the uncertainty in traffic restrictions. This situation hampers it to plan transportation routes and caused transportation costs to increase. The increase in China's logistics costs can be given as an example to this. According to a research conducted in China, it was determined that $51.7 \%$ of the logistics companies in China were damaged in the first quarter of 2020 (CFLP, 2020).

\section{NEW INCLINATIONS ON LOGISTICS AND SUPPLY CHAIN MANAGEMENT}

\subsection{Localization in Purchasing and Slippage in Production Zones}

With the transition of the first global impacts of the COVID-19 pandemic and the controlled normalization process, it is thought that there will be significant changes in supply chains and logistics activities. The biggest changes expected can be listed as localization in procurement, being easily accessible to suppliers and customers, flexible approaches regarding product diversity and stocks, dynamism, and digitalization, and determining alternative suppliers, logistics service providers and distribution channels. Furthermore, companies in many sectors are expected to diversify sources in supply and to engage in efforts to create local alternatives when it is appropriate (SAM, 2020).

When it comes to shifting production areas, before the pandemic, China accounted for $30 \%$ of world production. This rate has decreased after the pandemic. When the future forecasts are examined, the search for alternative production areas has begun. the manufacturers and the logistics sector in Turkey are expected to benefit (Şeker et al., 2020: 635).

\subsection{Accelerating Digital Transformation}

The logistics industry has challenges related to high efficiency, flexibility, fast action, and decision making in response to customer needs. The ability of businesses to overcome these challenges depends on the way they use and manage modern technologies. This represents a transformation. This transformation, called Logistics 4.0; It includes the use of high technology sensors and advanced robotics in logistics operations, and the connection of the entire SC with information technologies (Jahn et al., 2018). Cooperation, coordination and communication between suppliers, manufacturers, retailers, and customers within a SC can be achieved through digital transformation and process automation (Tjahjono et al., 2017: 1175). Logistics 4.0 will be the transformation process that makes a big difference for businesses in our world where SCs are competing, not companies.

Due to COVID-19, companies' transition to remote working system has once again demonstrated the significance of digital transformation in supply chain and logistics. More data-driven decision making, and data-driven logistics operations are expected to emerge from now on (Choi, 2020: 5). Digital transformation is of great importance as the smart and correct use of information accelerates decision-making processes (Choi et al., 2006: 789; Li et al., 2020: 961). It is anticipated that after the pandemic, automation and artificial intelligence investments will increase in the SCs, the use of more intensive information communication technologies and technological capabilities will be increased in this context. However, cyber security investments are expected to increase as cyber risks will increase with digital transformation (UTIKAD, 2020: 16).

New technologies that enable digital transformation increase supply chain visibility. Furthermore, these technologies provide an increase in supply chain agility and flexibility. It is also advantageous for these technologies to provide this without the "overhead" in terms of supply chain risk management (Kilpatrick and Barter, 2020: 14). In Deloitte's research titled Winners and Losers in the Supply Chain After Covid-19, efforts to increase operational visibility among the prominent focal points have come to the fore in almost all sectors, alternative ways of doing business and automation have taken their place among other significant focal points. (Deloitte, 2020: 7). This will be possible with the acceleration of digital transformation. The impact of COVID-19 on supply chain flexibility is detailed below. 


\subsection{Transition to Flexible SCs}

Just in time systems are designed to produce and deliver the needed goods or services by using the lowest level of stock. These systems are a logistics philosophy designed to reduce ineffective situations and non-production time in the production process and are used by many production enterprises (Lai et al., 2003: 265). Lean implementations are a logistics strategy focused on eliminating redundancies, reducing stocks, and increasing profitability. The main purpose of lean logistics is to perform all logistics operations with the least use of resources (labor, stock, equipment, time, etc.) and with the lowest cost (Nebol, 2017: 22-23).

Before the COVID-19 pandemic, especially in the last two decades, SCs were planned with just-in-time production approaches, where stocks were minimal or even zero stocks worldwide. With this approach, it was aimed to minimize inventory costs throughout the SC. However, with the pandemic, it has been understood that this approach has greatly reduced the flexibility of companies. Therefore, another prediction is that after the pandemic, it will be almost impossible for companies to implement managerial approaches that require working with minimum stock, such as lean SC, just-in-time production system (Brakman et al., 2020).

Flexible SC is among new applications in supply chain and logistics. The two main views on this issue are the number of product types that can be produced in each production unit and the process flexibility of the SC. Furthermore, product, process, route, and capacity flexible SC applications are also available (Sanchez and Perez, 2005: 683). As the disruptions in the SC during the pandemic process indicate the need for shorter and flexible SCs, the importance of them will increase in the future (Sanders, 2020).

\subsection{New Trends in Consumption}

The increase in the utilization of digital media by consumers with the pandemic caused an increase in e-commerce volumes (UTIKAD, 2020: 16). In addition to some sectors such as ready-to-wear, electronic goods, personal care and cosmetics, the food sector has started to gain a place in the e-commerce market with the pandemic. During the pandemic period, interest in ecommerce has increased. Even the middle-aged and older consumers, who seem the most distant, have changed their consumption habits in this period and have started to use e-commerce channels. According to the data of COVID-19 Commerce Insight, it is seen that retail consumption revived through e-commerce in the April-May 2020 period, when the pandemic peaked in the world, and retail consumption returned to its old level with the return to normal. Looking at Turkey's data, it is clearly seen that this upward trend became both more and more permanent in the same period. Compared to March 15, the increase in retail trade through e-commerce reached 200 percent in Turkey. As of mid-August 2020, this level continues with fluctuations. It is seen that the product groups most affected by the increase in e-commerce are cleaning, health, and food products. The change in ecommerce for the United Nations, United Kingdom, Germany, and Turkey is shown in Figure 3 below (COVID-19 Commerce Insight, 2020):

Figure 3: The Change in E-Commerce- Jan 2020-Aug 2020

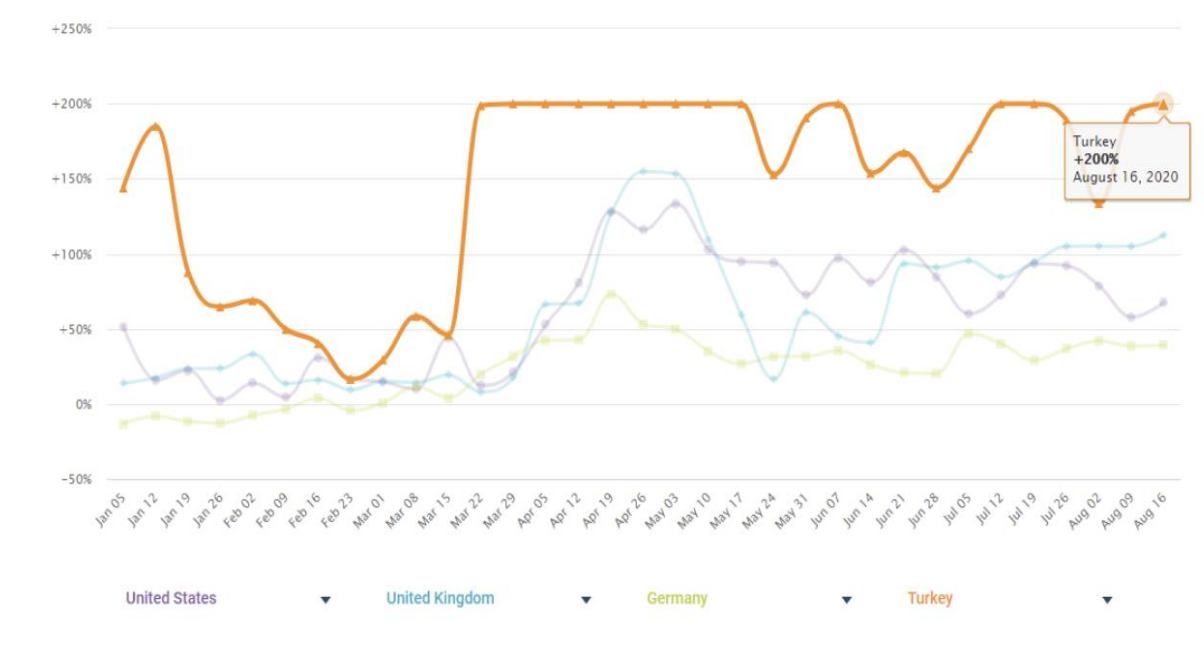

Source: COVID-19 Commerce Insight, (2020). Retrieved from www.ccinsight.com Access date 29 May 2021. 
As seen above, in the period including the first eight months of 2020, there has been a significant increase in e-commerce, especially between March and May. Moreover, it seems that e-commerce has not returned to its pre-COVID-19 level. In addition to the change in e-commerce, there has been a change in individual purchasing behavior with the impact of COVID-19. Panic buying and the tendency towards home consumption products has increased (Loske, 2020: 6). The first goods that consumers turn to during the pandemic are toilet paper, canned food, and other household cleaning products. One of the categories with the fastest rise in demand was disposable gloves with $670 \%$, bread making machines with a $652 \%$ rise, and cough and cold product groups ranked third. However, suitcases and briefcases are ranked as e-commerce products that have experienced the biggest decrease in sales by $77 \%$ since March last year. In addition, the demand for cameras and swimsuits fell by $64 \%$ and the demand for wedding dresses by $63 \%$ (Styrk, 2020).

\subsection{A New Concept Highlighted: Co-opetition}

For global SCs, they will spread the procurement, production, storage, and sales activities of companies as much as possible to different regions and even continents of the world. In this way, they will be able to protect their SCs against unexpected risk situations such as disasters and epidemics that may occur in the future. Companies will begin to implement new SC strategies. Coopetition, also known as cooperation with competitors, will be one of them (Sanders, 2020). Nowadays, companies living together is the only way to stay up to date in the ever-changing business world. Companies in the same industry should partner with each other. For instance, there is a growing problem between online and offline retailers in India. In such a situation, the competition between the two companies must be shifted towards cooperation that will benefit customers (Dinesh and Muniraju: 2021: 125).

\subsection{Mitigating the Effects of the Crisis: Crisis Management}

Crisis management is about control and "getting the job done". The goal of crisis management is to organize, manage, implement actions that minimize the effect of a threat and return to the pre-crisis period with minimal damage and loss (Boin and 't Hart, 2003: 544; Boin et al., 2013: 79). With the COVID-19, the significance of crisis management in supply chain and logistics management has been understood once again.

There are three important issues to reduce or eliminate the impacts of COVID-19 on the SC. These consist of crisis management, short term plans and medium-term plans. For crisis management, it is necessary to update the SC priorities, ensure the continuity of SC operations and manage customer and supplier relations. For mitigating the effect of the pandemic, short-term plans should be measuring supply and demand impacts, determining alternative supply strategies, evaluating operational risks, and planning scenarios. Medium-term plans require visibility throughout the SC, model and manage risk, and design and manage resilient SCS (PWC, 2020).

\subsection{Resilient SCS}

Resilience is the system's rapid adaptation and return to its original state after disruptions. It shows the high level of adaptation power of the system by returning to its previous state or approaching after the deterioration (Christopher and Peck, 2004: 2). The concept of resilience is confused with the concept of robustness. There are some differences between these two concepts. The most important difference between these two concepts; While robustness is the ability of the supply chain to continue in the same way against disruptions, resilience is how quickly the supply chain structure can recover despite disruptions (Karli and Tanyaş, 2020: 178).

In the COVID-19 era, companies have better understood that they need to increase the resilience of global supply chains to face disruptions triggered by serious disasters. Supply chain resilience (SCR) is an organization's ability to recover from supply chain disruptions and adapt quickly to adversity or disruption (Kumar and Singh, 2019). During the current crisis period, some important actions that need to be implemented in order to ensure resilience in enterprises have been emphasized. These are important actions based on business continuity and emergency management practices and are detailed below (Büyüközkan, 2020: 20):

- Establishing and maintaining a crisis command center,

- Supporting employees and company strategy,

- Ensuring business continuity and financing,

- Being in regular (continuous) communication with customers,

- $\quad$ Strengthening digital capabilities,

- Interacting with the business ecosystem and preparing for the "new normal".

- Focus and strengthen the supply chain. 
Companies and their supply chains should pay attention to the above actions to overcome possible future supply chains such as this pandemic with the least negative impact. A resilient supply chain can quickly revert to their original state or even more so to a new and more desirable state after being interrupted (Behzadi et al., 2020: 145; Behzadi et al., 2018: 21; Christopher and Beck, 2004: 1).

\subsection{Humanitarian Logistics}

Disasters, migration, epidemics such as COVID-19 and similar humanitarian crises across the world are factors that increase the need for aid activities. Disasters and global crises are causing devastating effects on people. These are increasing the importance of studies on improving logistics activities before and after disasters day by day. Especially in recent years, the significance of effective management of humanitarian logistics has increased (Senir, 2021: 296). In humanitarian aid logistics, it is aimed to provide humanitarian support by meeting needs such as medical supplies, water, food, and shelter. In humanitarian crises, logistics is vital as it acts as a bridge between disaster preparedness and response, supply, and distribution, as it is the center of all mobilization activities (Daud et al.,2016: 107-108).

Due to the pandemic, China provided medical supplies and cash aid to many countries. Some of these include Turkey, United Arab Emirates, Germany, France, England, Japan, Qatar, Azerbaijan, Russia, and Iran. Turkey is among the countries in this process also help to other countries. Turkey, mainly overalls, N95 and surgical masks, shields and protective gear such as goggles, gloves, was found in medical material aid consisting of antiseptics and test kits (T.R. Ministry of Health, 2020).

In the COVID-19 outbreak, protecting the most vulnerable has become not only a moral imperative but an urgent public health goal; The philosophy of "one's health is everyone's health" has gained importance (San Lau et al., 2020). In many countries, the most common type of aid sent is the distribution of supplies. However, the COVID-19 outbreak of processes, training of health care workers in Yemen, mosques cleaning in Indonesia and pesticide, and health center renovation in Romania, 3D printers donation and Gaza hospital grants to the Sudan, Turkey within the scope of the service benefits countable (TiKA, 2020).

\section{CONCLUSION}

The COVID-19 pandemic has a very significant global impact on supply chains by causing a disruption in the supply chain. The significance of supply chain risk management was better understood in this period, and the effects of the pandemic negatively affected supply chains and logistics. However, these negativities have drawn a new path for supply chains by showing that many understandings, strategies, and approaches that were in practice before the pandemic were wrong.

When the negative effects of the pandemic are examined, it can be counted that it causes a bullwhip effect in the supply chains, the decrease in the carrying capacity, the contraction of the international trade volume, which is an indispensable part of logistics, and the increase in logistics costs. Considering the new approaches and strategies that can be called new inclinations in the supply chain during the pandemic period, the understanding of localization in purchasing and shifting to new production regions is a significant part of the new inclinations. The significance of digital transformation has been better understood in this process and it is now seen as a compulsion rather than a necessity by companies. Furthermore, the significance of supply chain visibility was emphasized once again. It has once again emerged that the visibility and flexibility of digital transformation in supply chains has increased. The importance of crisis management has increased with the pandemic. Moreover, the fact that supply chain flexibility serves to provide the least damage from the crisis has increased the importance of supply chain flexibility exponentially. In this era, the importance of the concept of co-opetition, which existed before but unknown during the pandemic era, was understood. With the change in the consumption habits of consumers, the share and significance of new trade channels in consumption has changed. The value of humanitarian aid logistics was also emphasized during the pandemic.

When the effects of the pandemic on supply chains and new inclinations in supply chains are examined during the COVID-19 pandemic period, it has become important for supply chains to proactively carry out risk management studies to overcome an environmental risk such as a pandemic with the least damage. It has been revealed that the companies and supply chains that have felt the effects of the pandemic the least are those who perform risk management proactively. Considering that such pandemics will recur, companies need to increase their supply chain resilience to cope with these risks, whether there is a pandemic risk or different risks that may arise. Firms must take the necessary actions to create resilient supply chains. These are the two best recommendations for future risks. In addition to these recommendations, companies should increase their investments in digital transformation and transform their supply chains into interconnected and autonomous ecosystems. Supply chains transformed into interconnected and autonomous ecosystems will be the winning supply chains of tomorrow. 


\section{REFERENCES}

Airports Council International (ACI), (2020). Advisory bulletin 01. COVID-19: relief measures to ensure the survival of the airport industry. Retrieved from https://asianaviation.com/wpcontent/uploads/Policy Brief_COVID19 Relief Measures to Ensure the Survival_of the Airport Industry 2020.pdf. 05.06.2020

Akkermans, H. and Voss, C. (2013). The service bullwhip effect. International Journal of Operations \& Production Management, 33(6), $765-788$.

Akbal, H. (2020). COVID-19 Pandemisinin sağlık tedarik zincirine kamçı etkisi. Kesit Akademi Dergisi, 6(25), 181-192. http://dx.doi.org/10.29228/kesit.46950

Albers, S. and Rundshagen, V. (2020). European airlines strategic responses to the covid-19 pandemic (January-May, 2020). Journal of Air Transport Management. 87(2020), 1-6. https://doi.org/10.1016/j.jairtraman.2020.101863

Anbumozhi, V., Kimura, F. and Thangavelu, S. M. (2020). Global supply chain resilience: vulnerability and shifting risk management strategies. In Supply Chain Resilience. Singapore: Springer, 3-14.

Barua, S. (2020). Understanding coronanomics: The economic implications of the coronavirus (COVID-19) pandemic. SSRN Electronic Journal, doi:10.2139/ssrn.3566477, 7, 15-16.

Behzadi, G., O'Sullivan, M. J. and Olsen, T. L. (2020). On metrics for supply chain resilience. European Journal of Operational Research, 287(1), 145158.

Behzadi, G., O'Sullivan, M. J., Olsen, T. L. and Zhang, A. (2018). Agribusiness supply chain risk management: A review of quantitative decision models. Omega, 79, 21-42.

Behzad. B., Moraga, R. J. and Chen, S. J. (2011). Modelling healthcare internal service supply chains for the analysis of medication delivery errors and amplification effects. Journal of Industrial Engineering and Management, 4(4), 554-576.

Boin, A., Kuipers, S. and Overdijk, W. (2013). Leadership in times of crisis: A framework for assessment. International Review of Public Administration, 18(1), 79-91.

Boin, A. and t'Hart, P. (2003). Public leadership in times of crisis: mission impossible? Public Administration Review, 63(5), 544-553.

Budak, F. and Korkmaz Ş. (2020). COVID-19 pandemi sürecine yönelik genel bir değerlendirme: Türkiye örneği. Sosyal Araştırmalar ve Yönetim Dergisi, 1, 62-79.

Büyüközkan, G. (2020). COVID-19 salgını ile mücadelede dirençli tedarik zincirleri. LODER Bülteni 2020-1, 18-23.

CFLP, (2020). Investigation report on the environment for logistics and supply chain enterprises to resume production in 2020. Retrieved from http://www.chinawuliu.com.cn/lhhzq/202005/20/504479.shtml (In Chinese). 29.05.2021.

Christopher, M. and Peck, H. (2004). Building the resilient supply chain. The International Journal of Logistics Management, 15(2), 1-14. https://doi.org/10.1108/09574090410700275

Choi, T. M. (2020). Risk analysis in logistics systems: a research agenda during and after the COVID-19 pandemic. Transportation Research Part E: Logistics and Transportation Review, 145, 1-8.

Choi, T. M. J., Li, D. and Yan, H. (2006). Quick response policy with Bayesian information updates. European journal of operational research, 170(3), 788-808.

COVID-19 Commerce Insight, (2020). Retrieved from www.ccinsight.com. 29.05.2021.

Daud, M. S. M., Hussein, M. Z. S. M., Nasir, M. E., Abdullah, R., Kassim, R., Suliman, M. S. and Salu-Din, M. R. (2016). humanitarian logistics and its challenges: The literature review. International Journal of Supply Chain Management, 5(3), 107-110.

Deloitte, (2020). COVID-19 sonrası "yeni"den tedarik zinciri. Retrieved from

https://www2.deloitte.com/content/dam/Deloitte/tr/Documents/consulting/COVID-19-sonrasi-yeniden-tedarik-zinciri.pdf 4.06.2021.

Dinesh, S. and MuniRaju, Y. (2021). Scalability of e-commerce in the COVID-19 era. International Journal of Research-GRANTHAALAYAH, 9(1), 123128.

Disney, S.M., Farasyn, I., Lambrecht, M., Towill, D.R. and Van de Velde, W. (2006). Taming the bullwhip effect whilst watching customer service in a single supply chain echelon. European Journal of Operational Research, 173, 151- 172.

Drewry World Container Index, (2021). Retrieved from https://www.drewry.co.uk/supply-chain-advisors/supply-chain-expertise/worldcontainer-index-assessed-by-drewry 04.05.2021.

EUROCONTROL. (2020). Five-Year forecast 2020-2024. European flight movements and service units three scenarios for recovery from COVID-19. Retrieved from https://www.eurocontrol.int/sites/default/files/2020-11/eurocontrol-five-year-forecast-europe-2020-2024.pdf 04.05.2021. 
European Commission (2020a). COVID-19: Temporary restriction on non-essential travel to the EU. Retrieved from https://eurlex.europa.eu/legalcontent/EN/TXT/PDF/?uri=CELEX:52020DC0115\&from=EN. 29.04.2020

European Commission, (2020b). European economic forecast. Spring 2020, Institutional Paper 125, 27.06.2020.

Freund, C. and N. Rocha. (2011). What constrains Africa's exports? World Bank Economic Review, 25(3), $361-86$.

Gopinath, G. (2020). The great lockdown: Worst economic downturn since the great depression, IMF Blog. Retrieved from https://blogs.imf.org/2020/04/14/the-great-lockdown-worst-economic-downturn-since-the-greatdepression/ 29.05 .2021$.

Hassan, U. and Soh, B. (2005). Using adaptive web service multi agents for collaborative forecasting and countering bullwhip effect in SCM. In International Conference on Integration of Knowledge Intensive Multi-Agent Systems, 567-572. IEEE.

Hoekman, B. (2020). A 21st century trade agenda: global supply chains and logistics services. Retrieved from https://www.wto.org/english/forums_e/public_forum12_e/art_pf12_e/art5.htm 06.05.2021.

International Air Transport Association IATA, (2020a). Deep losses continue into $2021 . \quad$ Retrieved from https://www.iata.org/en/pressroom/pr/2020-11-24-01/ 13.05.2021.

International Air Transport Association IATA, (2020b). Air cargo market analysis, October 2020. Retrieved from https://www.iata.org/en/iatarepository/publications/economic-reports/air-freight-monthly-analysis---october-2020/06.05.2021.

International Civil Aviation Organization ICAO, (2020). Effects of novel coronavirus (COVID-19) on civil aviation: Economic impact analysis. Retrieved from https://www.icao.int/sustainability/Documents/COVID19/ICAO\%20COVID\%202020\%2005\%2026\%20Economic\%20Impact.pdf. 21.06.2020

International Union of Railways UIC, (2020). Railsilience: How the rail sector fought COVID-19 during lockdowns. Retrieved from https://uic.org/IMG/pdf/railsilience__how_the_rail_sector_fought_covid-19_during_lockdowns.pdf May 2020.

International Road Transport Union IRU, (2020a). COVID-19 Impact on the Road Transport Industry Update: November 2020. Retrieved from https://www.iru.org/resources/iru-library/covid-19-impact-road-transport-industry-update-november-2020 06.05.2021.

International Road Transport Union IRU, (2020b). COVID-19: how some countries around the world are supporting road transport. Retrieved from https://www.iru.org/resources/newsroom/covid-19-how-some-countries-around-world-are-supporting-road-transport 06.05.2021.

Jahn, C., Kersten, W. and Ringle, C. M. (2018). Logistics 4.0 and sustainable supply chain management: innovative solutions for logistics and sustainable supply chain management in the context of industry 4.0. Proceedings of the Hamburg International Conference of Logistics (HICL). Berlin: epubli $\mathrm{GmbH}$

Juttner, U. (2005). Supply chain risk management-understanding the business requirements from a practitioner perspective. International Journal Logistics Management, 16(1), 120-141.

Karli, H. and Tanyaş, M. (2020). Pandemi durumunda tedarik zinciri risk yönetimine ilişkin öneriler. İstanbul Ticaret Üniversitesi Sosyal Bilimler Dergisi, 19(37), 174-190.

Kilpatrick, J. and Barter, L. (2020). COVID-19: managing supply chain risk and disruption. Canada: Deloitte.

Kraemer, M. U., Yang, C. H., Gutierrez, B., Wu, C. H., Klein, B., Pigott, D. M., ... and Scarpino, S. V. (2020). The effect of human mobility and control measures on the COVID-19 epidemic in China. Science, 368(6490), 493-497.

Kumar, P. and Singh, A.P. (2019). Flexibility in service operations: review, synthesis and research agenda. Benchmarking: An International Journal, 27 (7), 2108-2129.

Lai, C. L., Lee, W. B., and Ip, W. H., (2003). A study of system dynamics in just-in-time logistics. Journal of Materials Processing Technology. 138(13), p. 265.

Lee, H. L., Padmanabhan, V. and Wang, S. (1997). Information Distortion in a Supply Chain: The Bullwhip Effect. Management Science, 43(4), 546558.

LODER Lojistik Derneği (2020). Koronavirüs tedarik zincirlerini kırdı, Yazar: Tanyaş Mehmet. pp. 1-3. Retrieved from https://mcusercontent.com/833f5af578ece3a8381433fe4/files/34ca29b5-c471-45f1-ae64-

2ada1c980a98/Koronaviru_s_LODER_Gorusu_24_03_2020_1_.pdf 08.05.2021.

Loske, D. (2020). The impact of COVID-19 on transport volume and freight capacity dynamics: An empirical analysis in German food retail logistics. Transportation Research Interdisciplinary Perspectives, 6, 100165.

Li, G., Li, L., Choi, T. M. and Sethi, S. P. (2020). Green supply chain management in Chinese firms: Innovative measures and the moderating role of quick response technology. Journal of Operations Management, 66(7-8), 958-988. 
Li, Q. and Gao, Y. (2010). Service Supply Chain and Its Bullwhip Effect. IEEE International Conference on Management and Service Science, Wuhan, China, pp. 1-3.

Li, T. (2020). A SWOT Analysis of China's air cargo sector in the context of COVID-19 Pandemic. Journal of Air Transport Management. 88(2020), $1-6$.

Lichun, T. and Jiayu, L. (2011). Simulation analysis of bullwhip effect in logistics service supply chain based on vensim. IEEE International Conference on Management and Service Science, Wuhan, China, pp. 1- 4.

Nebol E. (2016). Tedarik Zinciri ve Lojistik Yönetimi. Ankara: Nobel Akademik Yayıncılık.

PWC, (2020). COVID-19: Operasyonlar ve tedarik zinciri etkisi. Retrieved from https://www.pwc.com.tr/tr/Hizmetlerimiz/danismanlik/tedarikzinciri-yonetimi/covid-19-operasyonlar-ve-tedarik-zinciri-etkisi.pdf 28.05.2021

Republic of Turkey Ministry of Foreign Affairs, Center for Strategic Studies SAM (2020). COVID-19 sonrası küresel sistem: Eski sorunlar, yeni trendler. Retrieved from http://sam.gov.tr/tr/wp-content/uploads/2020/04/sam-covid-kitap.pdf 06.05.2021.

Prichep, E. (2020). Why a coronavirus vaccine takes over a year to produce-and why that is incredibly fast. In World Economic Forum. April (Vol. 3).

Saenz M. J. and Revilla, E. (2014). Creating more resilient supply-chains. MIT Sloan Management Review. Retrieved from https://sloanreview.mit.edu/article/creating-more-resilient-supply-chains/ 13.10.2019.

Sanchez M. A., and Perez P. M. (2005). Supply chain flexibility and firm performance: A conceptual model and empirical study in the automotive industry. International Journal of Operations \& Production Management, 25(7), 681-700.

Sanders N. R. (2020). COVID-19 Supply-chain disruption, treasury \& risk, Retrieved from https://www.treasuryandrisk.com/2020/03/19/covid-19supply-chain disruption/?slreturn=20200428142138 06.05.2021.

San Lau, L., Samari, G., Moresky, R. T., Casey, S. E., Kachur, S. P., Roberts, L. F. and Zard, M. (2020). COVID-19 in humanitarian settings and lessons learned from past epidemics. Nature Medicine, 26(5), 647-648.

Styrk, J. (2020). Top 100 Fastest growing \& declining categories in ecommerce. Retrieved from https://www.stackline.com/news/top-100gainingtop-100-declining-e-commerce-categories-march-2020 22.04.2020.

Shapiro, R. D. (1984). Get leverage from logistics. Harvard Business Review. 62(3), 119-126.

Singh, S., Kumar, R., Panchal, R. and Tiwari, M. K. (2020). Impact of COVID-19 on logistics systems and disruptions in food supply chain. International Journal of Production Research, 1-16.

Senir, G. (2021). COVID-19 salgınında insani yardım lojistiğinin ve tedarik zinciri yönetiminin önemi. Fiscaoeconomia, 5(1), 296-308.

Şeker, M., Özer, A. and Korkut, C. (Eds.). (2020). Küresel salgının anatomisi: Insan ve toplumun geleceği. Ankara: Türkiye Bilimler Akademisi.

Taşkın, B. K. (2020). Tedarik zinciri risk ve belirsizlikleri: Koronavirüs pandemisi ve ortamında ilaç sektöründe risk yönetimi ve halkla ilişkiler. İstanbul Arel Üniversitesi Iletişim Çalışmaları Dergisi, 8(17), 107-130.

Tjahjono, B., Esplugues, C., Ares, E. and Pelaez, G. (2017). What does Industry 4.0 mean to supply chain? Procedia Manufacturing, 13, $1175-1182$.

Turkish Statistical Institute TUIK, (2020). Retrieved from https://data.tuik.gov.tr/Bulten/Index?p=Dis-Ticaret-Istatistikleri-Aralik-2020-37412 22.04.2021.

T.R. Ministry of Health, (2020). Retrieved from https://www.saglik.gov.tr/ 28.04.2021.

Turkish Cooperation and Coordination Agency Directorate TiKA, (2020). Retrieved from https://www.tika.gov.tr/ 30.04.2021.

UNESCAP, (2020). COVID-19 pandemic: International freight trains lead the way into future. Retrieved from https://www.unescap.org/blog/covid19-pandemic-international-freight-trains-lead-way-future 30.04.2021.

UNCTAD. (2020). Handbook Of statistics. Retrieved from https://unctad.org/system/files/officialdocument/tdstat45_en.pdf 28.04.2021.

Waters, C. D. J. (2003). Logistics: An introduction to supply chain management. Basingstoke: Palgrave Macmillan.

Weele, van, A. J. (2014). Purchasing and supply chain management: Analysis, strategy, planning and practice. (6th ed.) Boston: Cengage Learning.

World Economic Forum (2017). New models for addressing supply chain and transport risk, Geneva. Retrieved from http://www3.weforum.org/docs/WEF_SCT_RRN_NewModelsAddressingSupplyChainTransportRisk_IndustryAgenda_2012.pdf. 13.10.2019

World Health Organization WHO, (2020). Retrieved from https://www.who.int/dg/speeches/detail/who-director-general-sopening-remarks-atthe-media-briefing-on-covid-19-11-march-2020. 20.04.2021. 
World Trade Organization WTO, (2021). World trade primed for strong but uneven recovery after COVID-19 pandemic shock. Retrieved from https://www.wto.org/english/news_e/pres21_e/pr876_e.htm 29.05.2021.

Vidya, C. T. and Prabheesh K.P. (2020). Implications of COVID-19 pandemic on the global trade networks. Emerging Markets Finance and Trade, 56(10). 2409-2414.

Viswanadham, N., Desai, V. and Gaonkar, R. (2005). Bullwhip effect in integrated manufacturing and service networks. IEEE International Conference on Robotics and Automation, Barselona, Spain, April, pp. 2994- 2999. 